\title{
The utilization of coffee waste in supporting family food security
}

\author{
I Wayan Sunanjaya*, Ni Made Delly Resiani, I Made Rai Yasa \\ Assessment Institute for Agricultural Technology Bali Province, Jalan Bypass Ngurah Rai, \\ Pesanggaran, Denpasar, Bali, Indonesia
}

\begin{abstract}
Coffee is one of the leading commodities traded in the world and is a mainstay commodity for farmers in mountainous areas. The research objective is to increase the added value of the part of the coffee plant to increase income and food security for farmer families. The research was conducted in the Pupuan-Tabanan Bali robusta coffee agroforestry area, Januari 2017 to December 2020. Methods of data collection using the method of observation and discussion with the main actors who produce coffee in addition to seed study activities with the use of pruned water shoots from clone maintenance BP 308. Data analysis was carried out quantitatively and qualitatively. The results showed that the added value besides dry beans was obtained from water shoots, remaining productive pruning, unproductive old coffee, branches and twigs, and shade pruning. The yields of economic value are in the form of super cuttings, activated charcoal, exotic pots, and quality organic fertilizers from coffee skins, each of IDR 7,500,000; 120,000; 792,000; and 150,000.
\end{abstract}

\section{Introduction}

Coffee is one of the mainstay commodities in the Indonesian plantation sector which has a major contribution to the Indonesian economy, both domestically and internationally $[1,2,3]$ state that coffee plays a role in foreign exchange income, driving the economy both for farmers [4], and for other economic actors involved in planting, processing results from coffee beans to ready-to-drink coffee grounds, and also includes marketing [5]. According to Putri et all [6], coffee has been cultivated since the 15th century and until now coffee has become one of the most consumed beverages and has even been considered a modern lifestyle.

Based on data from the International Coffee Organization (ICO), Indonesia is the 4th largest coffee producing country (Coffea sp.) in the world with a production of 1,744,000 tons or $7 \%$ of the total world coffee production. Brazil ranks first with production of $4,140,000$ tons or 39 percent of the world's total coffee production, followed by Vietnam with 1,740,000 tons (17 percent), and Colombia with 858,000 tons (8 percent) [7].

Most of the coffee plantation businesses in Indonesia are smallholder plantations (96\%) with low productivity, low business capital, lack of an intensive technical culture that causes

* Corresponding author: wayansunanjaya@yahoo.co.id 
low levels of production and farmers' income [8]. The remaining 4\% are national and private plantations [9].

The distribution of coffee production in Indonesia is uneven across regions/provinces so that this will cause the coffee commodity base areas in Indonesia to be concentrated in only a few regions/provinces [10]. In Bali, the largest robusta coffee plantation area is in the production center in Tabanan Regency. As much as $49.06 \%$ are in Pupuan District. The productivity is still low $(0.6$ tons/ha) of coffee beans, while the potential productivity can reach 1.2 tons. The low productivity is due to the fact that many coffee plants are old/damaged $(20 \%)$. It is expected that about $10 \%$ of the old/damaged coffee can be rejuvenated and replaced with superior seeds. Based on information from the Bali Provincial Agriculture Office, coffee rejuvenation is recommended at the farmer level using BP 308 rootstock and still paying attention to technical guidelines for good coffee cultivation [11].

Coffee for farmers in the Pupuan coffee area is the most familiar agricultural commodity. Generally, coffee cultivation is carried out by small-scale farming families (less than $3 \mathrm{ha}$ ), starting from traditional to modern cultivation [12]. According to Wathon et all [13], coffee farmers in general only see the economic value of coffee plants from rice/HS seeds and a small number of them process it into coffee powder. It is also said that the contribution of the coffee plantation business to the economic activities of the population is not limited to coffee production alone, but also the opening of employment opportunities in the trade and service (transportation) sector.

Wathon et all [13] also stated that the orientation of utilizing other coffee organs does not yet exist in almost all coffee farmers in the Pupuan District, even though by thinking and acting more creatively, increasing the value of other organs can be done easily. Classic reasons accompany the reluctance to start so that its impact, economic and other value is wasted and will never be lifted. The concept that was raised to start is "making something out of nothing" which is based on the phenomenon that exists in the coffee area and the desire to get added value in the form of other income from coffee farming. Suteja [14] found that robusta coffee bean waste could be processed into aromatherapy room freshener, while [14$16]$ found the use of coffee grounds and coffee husk compost to increase the growth and development of curly chilies and [17] found the potential of coffee fruit peel as a food rich in antioxidants.

Based on this, research was conducted with the aim of obtaining economic added value by utilizing wasted coffee organs, so as to maintain family food security. Parts of the coffee plant other than seeds can be increased in economic value into family income, including: water shoots, branches/stems used for trimming and coffee husk waste.

\section{Methods}

\subsection{Place and Time}

The study was conducted in Pupuan District area, Tabanan Region by collecting samples of farmers along with their farm in 3 villages (Batungsel, Pujungan dan Belatungan). Period of study is from Januari 2017 to December 2020.

\subsection{Research Method}

Each person or group of people required different approaches to be able to adapt with the technology or solution to existing problem. Therefore, combination of different method is required to acquire a more accurate data. In solving different problems that are being faced by the farmers in Pupuan District area, Tabanan Region, thus several approaches are taken 
which are: (1). Transfer of Technology, which is the development of society through pinpoint transfer of technology, adjusting the component of technology with the needs of the farmer in each stage of coffee farming and directly in the farmer's land. (2) Entrepreneurship Capacity Building (ECB). This technique is used to develop entrepreneurship capabilities, perceiving and utilizing waste or other materials to become economic value. (3) The other method that is used is participative approach which is Focus Group Discussion of pioneer farmers and coffee observer, discussion and limited technical guidance towards farmers who are concentrated to coffee farm on a daily basis. The most important part of this data collecting process is equality, no differentiation of self-status as well as upholding problem solving and extending thinking horizon to a more creative way of utilizing waste. Openness in each farmer towards their job could lead to a better chance of acquiring accurate data as well as achieving solution together to increase the economic value of some parts of coffee that has not been monetized before.

Farmers on researched area on average has spent equal time between go to the farm, in house and other social interaction, therefore the data collecting is adjusted thoroughly with the condition of the farmer. The data is also collected from field farming instructor, nearby society leader and coffee observer/enthusiast. The place of discussion/interview is mostly in the farm and the farmer's house as well as during the time when farmer is concentrated to the coffee plants.

\subsection{Data collection and analysis}

Data collection is not limited by time and conducted in gradual continuity to the coffee farmers, officers or to coffee plant enthusiast. The total respondent is 60 people. The collected data consists of period of trimming maintenance and the total number of growing water buds are potential for entrees, management of trimming residuals (post-harvest trimming, maintenance/production and rehabilitation/rejuvenation). The observation is repeated three times. The observation is conducted by collecting data in the special trimming field. The observation is conducted in the farmer's farm. The method of collection is by random sampling. The research of multiplication with super entrees cutting (mini water buds), making of exotic vase from the residual branch from the trimming. The data is collected descriptively and presented in a table.

\section{Result and discussion}

\subsection{Biophysic characteristics of Pupuan District}

Pupuan District, with the following borders; North Side; Buleleng Regency, East Side: Selemadeg District; South Side: West Selemadeg District; West Side: Buleleng Regency (region map is disclosed). Pupuan District consists of 14 official villages, namely: Belimbing Village, Karyasari Village, Sanda Village, Batungsel Village, Padangan Village, Kebon Padangan Village, Jelijih Punggan Village, Pujungan Village, Pupuan Village, Bantiran Village, Pajahan Village, Sai Village, Munduk Temu Village and Belatungan Village. The total populations in 2017 is 42.670 (10.078 families) consisted of 21.352 men and 21.159 women and according to the data the majority (90\%) is working in farming industry especially in dry/farming land. The total population of potential working age is also substantial. The total area size of Pupuan District in 2017 is 17.764,00 ha, which consisted of 1.939,00 ha paddy field, $14.784,00$ ha farm land, 12,00 ha of basin, 228,00 ha of yard, 1501,00 .ha of forest, and 352,00 ha of other geographical feature. 
The topography in Pupuan District is hilly sloped with the angle of $5-80^{\circ}$ and the villages are located on the height of between 450-1200 above sea level. The field is characterized as clayey and some are sandy clay. The annual rainfall is about $3.776 \mathrm{~mm}$ with 184 times of rain. The position of Pupuan District is Tabanan Region. Indrawanto et all [18] stated that this coffee can grow well at altitudes above 600 to $700 \mathrm{~m}$ above sea level.

The development of Bangelan quality coffee clone (BP 42) has been developed in Pupuan District with the total of 7.740 hectare with the production of 3.733 ton annually. The location of the development is located in Pujungan, Kebon Padangan, Munduk Temu, Sanda, Batungsel, Munduk Temu, Belatungan, Jelijih Punggang, and Pajahan Village. Altogether those places are used as Pupuan Bali Robusta Coffee MPIG group. Situated in Pujungan Village, Pupuan District, Tabanan Regency, which is supported by 30 Subak Abian [11]. Production of dry seeds is considered low which is 0,6 -ton HS per hectare with the total population of 800-1000 trees. It is rare to find monoculture coffee farming. The maintaining of coffee plant which consisted of fertilizing, trimming, farm sanitation pest maintenance are often times less optimal than it should be [13].

\subsection{The existing cultivation technology in Pupuan District}

The existing cultivation of robusta coffee farmer in Pupuan Disrtict and the introduction technology which disseminated gradually is shown in Table 1.

Table1. The components of existing, technology and innovation technology which are disseminated in Pupuan District Tabanan.

\begin{tabular}{|c|c|c|c|}
\hline No & Technology Components & Existing & $\begin{array}{l}\text { Innovation } \\
\text { Technology }\end{array}$ \\
\hline 1. & $\begin{array}{l}\text { Weeding/farm } \\
\text { cleaning/weeds }\end{array}$ & $\begin{array}{l}\text { 1) } 1-4 \text { times annually } \\
\text { 2) Rorak establishment is not optimal } \\
\text { 3) The mower (Machine) partially is still small. }\end{array}$ & Machine, rorak \\
\hline \multirow[t]{2}{*}{2.} & Production trimming & $\begin{array}{l}\text { Not yet optimal, trimming is conducted on B2 } \\
\text { and the production is not trimmed or is just left } \\
\text { as it is. }\end{array}$ & Maximum B2 \\
\hline & Trimming of Wiwilan & Not punctual and only conducted at some point. & Punctuality \\
\hline 3. & Planting of shaders & $\begin{array}{l}\text { Shaders exists (gamal, lantoro) } \\
\text { Almost rarely used but not used on coffee plant, } \\
\text { and even considered as weeds. }\end{array}$ & $\begin{array}{l}\text { Shaders as } \\
\text { livestock food }\end{array}$ \\
\hline 4. & $\begin{array}{l}\text { Plantation initiation and } \\
\text { empons maintenance. }\end{array}$ & $\begin{array}{l}\text { Almost nonexistent, constrained due to } \\
\text { purification and cheap price. }\end{array}$ & $\begin{array}{l}\text { Conducted on } \\
\text { several potential } \\
\text { land }\end{array}$ \\
\hline 5. & Organic fertilizing & $\begin{array}{l}\text { Normally conducted, but at this moment is still } \\
\text { less for coffee } \\
\text { Already moving to organic fertilizer farming }\end{array}$ & $\begin{array}{l}\text { In accordance } \\
\text { with the dosage, } \\
\text { processed }\end{array}$ \\
\hline 6. & Inorganic fertilizing & $\begin{array}{l}\text { Normally conducted with the recommended } \\
\text { dosage }\end{array}$ & Recommendation \\
\hline 7. & Production of Rorak & $\begin{array}{l}\text { Production of rorak is conducted but not yet } \\
\text { optimal }\end{array}$ & $\begin{array}{l}\text { Production of } \\
\text { Rorak }\end{array}$ \\
\hline 8. & Land conservation (terrace) & Not yet optimal & $\begin{array}{l}\text { Terrace chair and } \\
\text { or terrace gambier }\end{array}$ \\
\hline 9. & Pest control & Not conducted & Biological agency \\
\hline
\end{tabular}

(Results of FGD, Friday, 29 March 2019) 
From the Table 1 above could be described that from the side of technology component of coffee cultivation in Pupuan District should just be optimized. The knowledge of the farmer is sufficient enough although technically still needs to be revised. From the aspect of technology of cultivation, some important issues that are need to be addressed are trimming of wiwilan in the very early stage or young wiwilan. The non-optimized cultivation activities are much related to the social condition of the people which is dominated by practicing social-culture-tradition, which is time consuming for the farmers in farming coffees. All individuals have different capabilities to develop their knowledge, because the target of socialization is vary which is regarding characteristic of the individuals, the environment both physically and socially, the needs, the motivation as wee as the intended purpose. The trimming of shape is conducted by cutting the highest primary branch by one segment, completely trim secondary branch in length of $20 \mathrm{~cm}$, afterwards pick 2-3 good secondary branch a well as having dispersed location in every primary branch for maintenance, therefore the rest is discarded. The production trimming or maintenance are conducted by discarding the water buds that grows upward, discarding worm branch as well as returning branch, discarding all weed and disease infested branch. Rejuvenating trimming is conducted by trimming all branches in one side, while leaving the other one [19-20].

\subsection{Efforts of Improving Added Value of Coffee Waste and Farmer's Income}

Dry coffee seed (HS)/rice coffee) as the main produce which has economic value, while the other parts cannot be optimized yet, namely: mini water buds, residual trimming branch for exotic vase, the residual trunks/branch and other branches for bio charcoal. Those materials can be re processed to gain added value, described as follow:

\subsubsection{Hard Seed and coffee skin}

The farmers in Pupuan District on average conducted dry processing with the main produce being sold is hard seed. Meanwhile the dry coffee skin which is acquired on average of 300 $\mathrm{kg}$ per hectare are laid waste or being returned to the farm or sold as much as $\mathrm{Rp} 500,00$ (Rp $150.000,00$ per hectare annually). Coffee seed processing yields additional produce coffee skin that is potential to become waste. The alternative solution which can be applied is to process the coffee skin waste to become a product in the form of coffee skin powder, bio charcoal, or coffee skin bran which can be utilized by the society [21]. On average the yields of dry seed is $800 \mathrm{~kg}$ per hectare could be processed properly even if not optimal just yet. The price per kilograms of hard seed at the time this activity conducted is Rp 22.000,00, therefore the income acquired is $17.600 .000,00$ annually.

\subsubsection{Added value of water buds}

The trimming of water buds from lower trunks could sometimes be done late or in mature conditions. The impact of this treatment towards the healthiness and production of coffee plants on the long run is unconsciously unconsidered. The remaining trims of the ater buds is laid waste or even disturbing the other activity in coffee maintenance especially the sanitization of the farm.

One of the causes of the low production of Robusta coffee is the lack of utilization of quality materials in the form of quality seed according to the environment. The habit of using materials from high yielding trees or even swept seeds is still widely seen. This causes the annual average productivity is low as the result of the plant is producing in substantial amounts twice a year. One of the solutions to increase the productivity of robusta coffee is to revised the material. The changing of recommended planting material could be applied 
gradually, either by grafting in the field on the existing coffee plants or by new planting with materials from cutting (stek).

The materials that are acquired from the location is better due to its long-term adaptation, the micro weather and the land of its growing supports the growth of the coffee plant. Therefore, the source of the seed is very much in situ. The sprouts in the form of water buds grow rapidly after the post harvesting trimming can be utilized as cutting (stek) source for seeds especially with the lower stem clone BP308. The average water buds that grow as minimum as 15 trunks can be used for source of seed. The added value of mini water buds which is usually discarded can be enhanced as the probable lower trunk coffee seeds. Trimming at a very early stage will yields new water buds three to four times. The result of water buds' utilization studies as lower trunk shows a better result compared to segments of grow water buds [13]. Water buds are priced Rp 500 and is utilized as a source of seed and in a year could yield a minimum.

Hulupi and Martini [22] Ibrahim and Hartati [23] stated that BP 308 clone is a highquality clone that can be used as lower trunks to spliced with th sprouts from other variant. The planting material is usually acquired from the cutting of the sprout, but the utilization of sprout from young water buds or wiwilan which has potential to be utilized has not been found. It begins from accident, acquiring discarded mini water buds could develop roots even if it is still attached to the main trunks. According to Sianturi and Wachjar [24] stated that water buds or wiwilan on coffee plant must be trimmed. If not, it will interfere with the fertilization because the plant's nutrition will be absorbed for the growth of the stem.

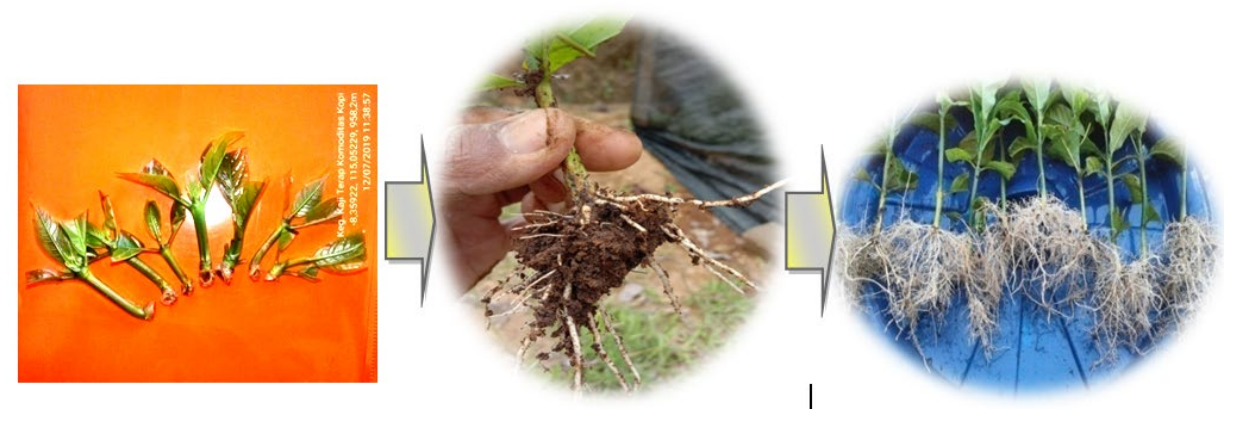

Fig 1. BP308 coffee seed from mini water buds

The apical meristematic trim will cuse the prodycetion and translocation of auxin to the lateral buds be halted, therefore the production of cytokinin hormone increased and afterwards the lateral growth and branch will happen at a faster pace. The cytokinin hormone functions in speeding up the formation of flower and fruit. Substantial branching could potentially yields clusters of space fro the growth of more flowers and fruits [23].

\subsubsection{Added value of branch and twig residual trimming for bio charcoal.}

The post-harvest trimming is conducted every post harvesting, reducing branches that have fertilized twice in a year, broken branch or being attacked by pest and diseases. Some farmers conducted trimming for the other, because there are some younger or older ones. The conducted trimmings are shape trimming or rejuvenating trimming when there are branches that do not or lacking producing once in a year and trimming 3 times a year [23].

Several months after the trimming, the remaining is buried or piled under the coffee tree and some are cut above the rorak. The weathering and decayed wood yielded from this trim is taking times therefore interfering with the sanitization of the farm. The experiment of 
making charcoal from the branch and twig or coffee wood can be done to increase the added value to become bio charcoal or active charcoal. The remains of the prunings after being cut for exotic pots are used for bio-charcoal. obtained 0.6-1.5 kg of activated charcoal per 2 coffee trees. On average every hectare yields income for bio charcoal of $120 \mathrm{~kg}$ annually, sold for Rp 1000,00, therefore the income is Rp 120.000,00 (Table 2)

Table 2. Added value of productive robusta coffee

\begin{tabular}{|l|l|l|l|r|}
\hline No & Decription & Volume & Rp & \multicolumn{1}{|c|}{ total (Rp) } \\
\hline 1. & Coffee skin waste (kg) & 300 & 500 & 150,000 \\
\hline 2. & Trim residuals for exotic vase (vase) & 264 & 3000 & 792,000 \\
\hline 3. & Water buds from lower trunk BP308 & 15.000 & 500 & $7,500,000$ \\
\hline 4. & Rice coffee seeds (kg) & 800 & 22.000 & $17,600,000$ \\
\hline 5. & Active charcoal/bio charcoal (kg) & 120 & 1000 & 120,000 \\
\hline & Total & & & $26,162,000$ \\
\hline
\end{tabular}

\subsubsection{Added value of branch and twig residual trimming in forms of vase}

The processing of coffee wood for product is also geared towards reducing coffee wood waste itself. This is due to the coffee tree that is not productive, cannot produce any more fruits again therefore rejuvenation/trimming must be conducted, and it is expected for the coffee wastes to be taken and recycled to become a more valuable product. Coffee wood has hard and firm characteristics; therefore, it has high volume.

One of the alternatives of other types of wood can diminish the use of rare woods is coffee wood. Coffee wood is chosen because this type of wood is everywhere in Indonesia and is considered as a waste for the society in the vicinity if the plant is not productive anymore. And from there, there is a big opportunity in utilizing wood to become added value product, especially to furniture and other interior elements, due to the similar characteristics with other processed wood that is used to for furniture in general [25].

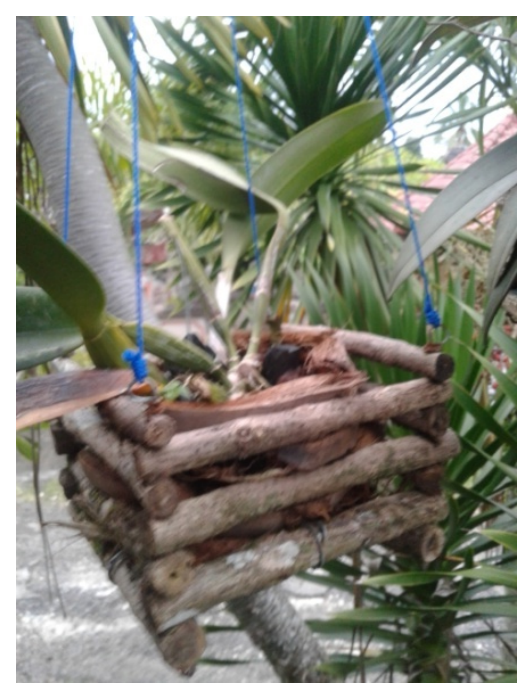

Fig 2. Exotic orchid vase from coffee wood 
This research regarding utilization of wood waste/branch/twig to become exotic orchid vase annually is 264 vases which is priced at Rp 3.000,00 per vase, therefore the total income is $\operatorname{Rp} 792.000,00$.

\section{Conclusion}

Added value of coffee in terms of branches, twigs, coffee wood, coffee skin, and the water buds can be enhanced. The additional income of the farmer increased by Rp 8.562.000,00 or increased by $32,73 \%$. Additional income can be used for family food security

Acknowledgement. Thank you for the Institute of Reasarch and Farming Development of Farming Department for the funding of this activity so that it can be conducted as well as the farmer as the respondent in Pupuan District.

\section{References}

1. D. Chandra, A. H. L. Dyah,, S. Suriati, J. H.A. 1,1 (2013)

2. I. Irmeilyana, N. Ngudiantoro, D.R. Rodiyah, Info media. 4,2, 60-68 (2019)

3. N. Fitriani Syam, N. Jufri, R. Sari, M. Mahendradatta, J. Ilmiah Pengab kepada Masy Agro. 5,3 (2019)

4. P. Rahardjo,. Panduan Budidaya dan Pengolahan Kopi Arabika dan Robusta. (ID): Penebar Swadaya, Jakarta, 2012)

5. E. Symartauli. J. of Agribus scient. 1,2 (2018)

6. J.M.A. Putri, K.A. Nocianitri, N.K. Putra. J. med. Ilmh. Tek Pang. 4, 2 (2017)

7. Bappebti . Badan pengawas perdagangan. http://bappebti.go.id . diakses 29 April 2021 (2020)

8. Suteja,,Managemen peremajaan tanaman kopi robusta pada perkebunan rakyat di kecamatan pupuan. (Program Study Agroekoteknologi Fakultas Pertanian, Universitas Udayana Denpasar, 2018)

9. Permentan, Peraturan Menteri Pertanian Nomor: 49/Permentan/OT.140/4/2014 tentang Pedoman Teknis Budidaya Kopi yang Baik (Good Agriculture Practices/GAP on Coffee). (Direktorat Jendral Perkebunan. Kementerian Pertanian 2015)

10. Kusmiati, A., Windiarti, R... J. J. 5, 2 (2011)

11. O. Parwata,. IW. Buda, I W. Sunanjaya,, Programa Penyuluhan Provinsi. (Dinas Pertanian Tanaman Pangan, Hortikultura dan Perkebunan Provinsi Bali, 2019)

12. B. Hafif, B. Prastowo, B. Prawiradiputra,. J. Peng. Iov. Pert. 7,4 (2014)

13. W. Sunanjaya, N. Adijaya, M. Sukadana, N. Duwijana, K. Kasih Sukraeni. Lap. Kaji Terap Inovasi Pertanian Komoditas Kopi. (Balai Pengkajian Teknologi Pertanian Bali., 2019)

14. S. Wathon, M. Ani, E. Utami. Warta Pengabdian. 14, 2 (2020)

15. N. P.T. Juliantari, L. Putu Wrasiati, Ni MD. Wartini. J. Rek, dan Manj Agro. 6,.3 (2018)

16. Z. Berlian, Syarifah, D. Selvia Sari. J. Bio. 1,1 (2015).

17. A. Marcelinda,A. Ridhay, Prismawiyanti. J. of Nat. Sience. 5, 1 (2016)

18. C. Indrawanto, E. Kamawati, Munarso, Prastowo, SJ, Rub, B, Siswanto.. Budidaya dan P ascapanen Kopi. Bogor (ID): (Pusat Penelitian dan Pengembangan Perkebunan, 2010)

19. R. Subantoro, M. Abdul Azis. J. Ilmu Pert. 15, 1 (2019)

20. D. Rizki, B. Rudianto, Wijonarko, Purwanto.J. Ilm. Pert. 2, 1 (2020)

21. S. Andi Nur Fajri, N. Fitriani Syam, N. Jufri, Rosnita Sari, M. Mahendradatta. J. Ilm. Pengab. Kepada Masy.Agro. 5, 3 (2019) 
22. R. Hulupi, E. Martini . Pedoman budidaya dan pemeliharaan tanaman kopi di kebun campur. (Word Agroforestry Centre (ICRAF). Bogor. (2013)

23. M.S.D. Ibrahim, R.R. Hartati. Improvement of Embryogenic Calli Induction and Somatic Embryo Conversion of Robusta Coffee Clone BP 308. Bogor. (2017)

24. V. Sianturi, A. Wachjar. Bul. Agrohorti. 4 ,3 (2016)

25. R. Christianto, A. Pandu Setiawan, F. Tanaya. J. Int. 7, 2 (2019) 